\title{
Inverse Potassium Hydride: A Theoretical Study
}

\author{
Agnieszka Sawicka, ${ }^{\dagger \neq}$ Piotr Skurski, ${ }^{\dagger, \ddagger}$ and Jack Simons $*, \dagger$ \\ Henry Eyring Center for Theoretical Chemistry, Department of Chemistry, University of Utah, \\ Salt Lake City, Utah 84112, and Department of Chemistry, University of Gdansk, \\ Sobieskiego 18, 80-952 Gdansk, Poland
}

Received: September 30, 2004; In Final Form: November 15, 2004

\begin{abstract}
Results of an experimental study on the unusual "inverse" charge state $\left(\mathrm{H}^{+} \mathrm{Na}^{-}\right)$in salts where the $\mathrm{H}^{+}$ion is sequestered, combined with our earlier theoretical calculations on an unsequestered model compound $\left(\mathrm{Me}_{3} \mathrm{~N}-\right.$ $\mathrm{H}^{+} \cdot \cdot \mathrm{Na}^{-}$), prompted us to further investigate such systems. In particular, we examined $\mathrm{Et}_{3} \mathrm{~N}-\mathrm{H}^{+} \cdot \cdots \mathrm{K}^{-}$because considerations of the proton affinity of the amine and of the metal-hydride bond strength suggested that this ion-pair complex might be more stable to proton abstraction than was $\mathrm{Me}_{3} \mathrm{~N}-\mathrm{H}^{+} . . . \mathrm{Na}^{-}$. In the present work, the ground-state potential energy surface of the $\mathrm{Et}_{3} \mathrm{~N}-\mathrm{H}^{+} \cdot \cdots \mathrm{K}^{-}$ion pair was examined using second-order Møller-Plesset perturbation theory and 6-311++ $\mathrm{G}^{* *}$ basis sets. We found $\mathrm{Et}_{3} \mathrm{~N}-\mathrm{H}^{+} \cdots \mathrm{K}^{-}$to be metastable to dissociation with a barrier of $8 \mathrm{kcal} \mathrm{mol}^{-1}$ (computed at the $\operatorname{CCSD}(\mathrm{T})$ level of theory). This barrier indeed is substantially larger than that found earlier for $\left(\mathrm{Me}_{3} \mathrm{~N}-\mathrm{H}^{+} \cdot \cdot \cdot \mathrm{Na}^{-}\right)$and suggests that unsequestered inversecharged $\mathrm{H}^{+} \mathrm{M}^{-}$ion-pair salts may offer a reasonable route to creating high-energy materials if a means for synthesizing them in the laboratory can be designed.
\end{abstract}

\section{Introduction}

A recent experimental investigation by the Dye ${ }^{1}$ group points to the existence of alkali hydride salts containing the unusual "inverse" charge distribution $\mathrm{H}^{+}$and $\mathrm{M}^{-}$. In the $\mathrm{H}^{+} \mathrm{Na}^{-}$salt they synthesized and characterized, the $\mathrm{H}^{+}$ion is bound to one or more of the nitrogen centers of a poly-amine and the $\mathrm{Na}^{-}$ alkali anion is "blocked" from approaching the protonated amine site by steric constraints of the cage structure as shown in Figure 1 .

As the authors of ref 1 explain, this "inverse sodium hydride" salt could be synthesized because the $\mathrm{H}^{+}$is sequestered within the amine in which the nitrogen center(s) are spatially isolated inside the $3^{6}$ adamanzane (Adz) hydrocarbon cage. The $\mathrm{Na}^{-}$ alkali ion cannot approach the $-\mathrm{NH}^{+}$center closely enough to achieve proton abstraction

$$
\mathrm{R}_{3} \mathrm{~N}-\mathrm{H}^{+}+\mathrm{Na}^{-} \rightarrow \mathrm{R}_{3} \mathrm{~N}+\mathrm{HNa}
$$

that would produce the much lower-energy $\mathrm{Na}^{+} \mathrm{H}^{-}$charge state. In another paper, the Dye group ${ }^{2}$ suggested that, in contrast, the $\mathrm{Na}^{-}$ion should be able to abstract the proton from unsequestered (i.e., in the absence of cage constraints) protonated amines, thus making the $\mathrm{M}^{-} \cdot \cdots \mathrm{H}^{+}$charge state impossible to maintain in the absence of such protection.

Such salts in which the alkali atom and hydrogen appear in their "inverse" charge states may be important because they represent high-energy states of alkali hydrides that might be used as building blocks in constructing new materials having high energy content. Therefore, we decided to explore how unstable the $\mathrm{M}^{-} \cdot \cdots \mathrm{H}^{+}$charge state is for different alkali anions $\mathrm{M}^{-}$and with amines of different proton affinities. Our idea has

* Corresponding author. E-mail: simons@chemistry.utah.edu.

University of Utah.

$\doteqdot$ University of Gdansk.

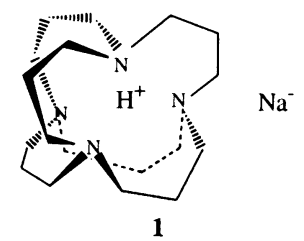

Figure 1. Structure of the ion pair appearing in the salt synthesized in ref 1 .

been to use an amine having a large proton affinity (to disfavor breaking the $\mathrm{N}-\mathrm{H}$ bond) and an alkali metal for which the $\mathrm{M}^{+-} \mathrm{H}^{-}$bond energy is small (to disfavor forming the $\mathrm{H}-\mathrm{M}$ bond) in the hopes of minimizing the thermodynamic driving force disfavoring the $\mathrm{R}_{3} \mathrm{~N}-\mathrm{H}^{+} \cdot \cdot \mathrm{M}^{-}$structure.

A. Previous Findings. In an earlier effort, ${ }^{3}$ we examined the possibility that species such as $\mathrm{R}_{3} \mathrm{NH}^{+} \cdot . \mathrm{M}^{-}$(with $\mathrm{M}$ being an alkali atom) might be metastable with respect to dissociation to form $\mathrm{R}_{3} \mathrm{~N}$ and $\mathrm{M}^{+} \mathrm{H}^{-}$(i.e., an amine plus a metal hydride in its conventional charge state). We examined the ground-state potential energy landscape of the prototypical unprotected system $\mathrm{Me}_{3} \mathrm{~N}+\mathrm{NaH}$ to determine whether the high-energy $\mathrm{Me}_{3} \mathrm{~N}-\mathrm{H}^{+} \cdot . \cdot \mathrm{Na}^{-}$ion pair might be stable with respect to proton abstraction both as isolated (i.e., gas-phase) species and under any reasonable solvation conditions (treated within the polarized continuum model). ${ }^{4}$

The MP2 energies obtained in the gas-phase connecting $\mathrm{Me}_{3} \mathrm{~N}$ $+\mathrm{NaH}$ to the $\mathrm{Me}_{3} \mathrm{~N}-\mathrm{Na}^{+} \cdot . \cdot \mathrm{H}^{-}$and the $\mathrm{Me}_{3} \mathrm{~N}-\mathrm{H}^{+} \cdot . \cdot \mathrm{Na}^{-}$ion pairs are shown in Figure 2, where $r$ is the distance from $\mathrm{N}$ to the hydrogen atom for the upper curve and the distance from $\mathrm{N}$ to the $\mathrm{Na}$ atom for the lower curve.

These findings suggest that the $\mathrm{Me}_{3} \mathrm{~N}-\mathrm{H}^{+} \cdot \cdot \mathrm{Na}^{-}$complex is locally geometrically stable but with a very small barrier to dissociation of ca. $700 \mathrm{~cm}^{-1}(2 \mathrm{kcal} / \mathrm{mol}$, computed at the $\operatorname{CCSD}(\mathrm{T})$ level for optimal accuracy). The local stability is also supported by the fact that this complex has all real harmonic 


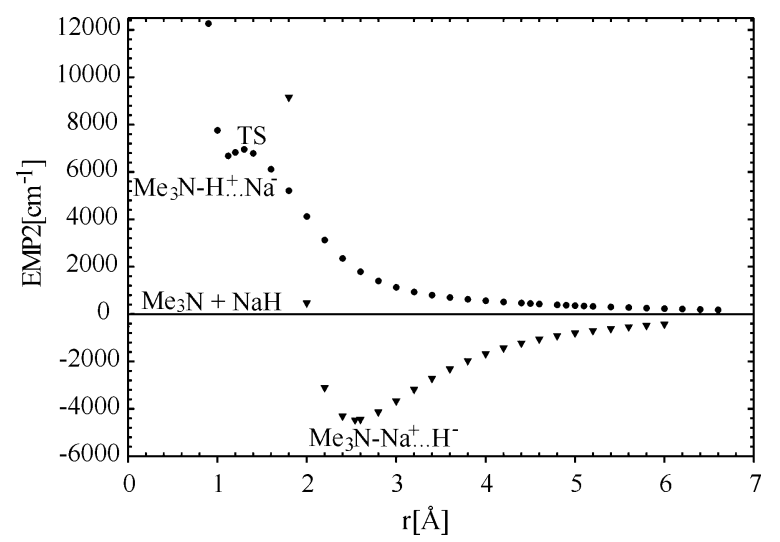

Figure 2. MP2 energies $\left(\mathrm{cm}^{-1}\right)$ connecting $\mathrm{Me}_{3} \mathrm{~N}+\mathrm{NaH}$ to (lower) $C_{3 v} \mathrm{Me}_{3} \mathrm{~N}-\mathrm{Na}^{+} \cdot \cdots \mathrm{H}^{-}$and to (upper) $C_{3 v} \mathrm{Me}_{3} \mathrm{~N}-\mathrm{H}^{+} \cdot \cdots \mathrm{Na}^{-}$(taken from ref 3).

vibrational frequencies. As Figure 2 illustrates, the $\mathrm{Me}_{3} \mathrm{~N}-\mathrm{H}^{+}$. $\cdot \cdot \mathrm{Na}^{-}$minimum lies ca. $6700 \mathrm{~cm}^{-1}$ above the $\mathrm{Me}_{3} \mathrm{~N}+\mathrm{NaH}$ asymptote that is the reference point (i.e., zero of energy) for all energies shown in Figure 2. It also shows that the complex in which the $\mathrm{Na}^{+}$ion is bound to the amine is ca. $11000 \mathrm{~cm}^{-1}$ more stable than the inverse-charge complex $\mathrm{Me}_{3} \mathrm{~N}-\mathrm{H}^{+} \cdot . \cdot \mathrm{Na}^{-}$.

The ground-state energy of $\mathrm{Me}_{3} \mathrm{~N}-\mathrm{HNa}$ as a function of the angle between the $C_{3}$ axis of the amine moiety and the $\mathrm{HNa}$ internuclear axis and of the distance $R_{\mathrm{NX}}$ from the nitrogen to the midpoint (denoted $\mathrm{X}$ ) of the $\mathrm{HNa}$ fragment is depicted in Figure 3.

In Figure 3a, the minimum corresponding to $\mathrm{Me}_{3} \mathrm{~N}-\mathrm{Na}^{+}$.. $\cdot \mathrm{H}^{-}$is indicated with an arrow. Figure $3 \mathrm{~b}$ and $\mathrm{c}$ shows the region near the protonated amine plus $\mathrm{Na}^{-}$complex (angle $=0$ ). The presence of the $\mathrm{Me}_{3} \mathrm{~N}-\mathrm{H}^{+} \cdot \cdot \mathrm{Na}^{-}$local minimum is especially distinct in Figure 3c. A contour plot of the MP2 energies in the region of this minimum and the transition state showing the radial and angular shape and depth of the minimum is presented in Figure 4. The local minimum corresponding to the $\mathrm{Me}_{3} \mathrm{~N}-$ $\mathrm{H}^{+} \cdot . \cdot \mathrm{Na}^{-}$complex appears near $R(\mathrm{~N}-\mathrm{X})=2.4 \AA$ and an angle of $0^{\circ}$, while the transition state is near $R(\mathrm{~N}-\mathrm{X})=2.5 \AA$ and an angle of $6^{\circ}$.

As mentioned above, the model compound studied in our earlier work was analyzed not only in the gas-phase but also in different solvation environments. We observed that in solvents with dielectric constants less than or equal to 2, a barrier separating the high-energy ion-pair $\mathrm{Me}_{3} \mathrm{~N}-\mathrm{H}^{+} \cdot \cdot \mathrm{Na}^{-}$from $\mathrm{Me}_{3} \mathrm{~N}+\mathrm{NaH}$ appears as shown in Figures 3 and 4, but in stronger solvents, this barrier disappeared. Our final suggestion was that the $\mathrm{Me}_{3} \mathrm{~N}-\mathrm{H}^{+} \cdot \cdot \mathrm{Na}^{-}$complex can be metastable for solvents having dielectric constants below ca. 2, but spontaneously decomposes into $\mathrm{Me}_{3} \mathrm{~N}+\mathrm{NaH}$ for solvents with higher dielectric constants. Because a $2 \mathrm{kcal} \mathrm{mol}^{-1}$ barrier is too small to allow the complex to be stable except at cryogenic temperatures, ${ }^{5}$ this particular choice of inverse-charged complexes likely is not of immediate use in the laboratory. Therefore, we decided to examine other $\mathrm{N}-\mathrm{H}^{+} \cdot . \cdot \mathrm{M}^{-}$candidates that do not have the $\mathrm{H}^{+}$sequestered.

B. The Model Compound Studied Here. In the present effort, we examined another unprotected protonated amine complex with potassium as the alkali metal and triethylamine as shown in Figure 5. After considering many alternatives, we chose this system because of the larger proton affinity of $\mathrm{Et}_{3} \mathrm{~N}$ than $\mathrm{Me}_{3} \mathrm{~N}$ and the weaker $\mathrm{K}-\mathrm{H}$ bond strength. ${ }^{6}$ Our earlier suggestion indicated that by using such amines and metal hydrides a $\mathrm{R}_{3} \mathrm{~N}-\mathrm{H}^{+} \cdot . \cdot \mathrm{M}^{-}$ion pair that is more stable and has a larger barrier to dissociation might be achieved. In future work,
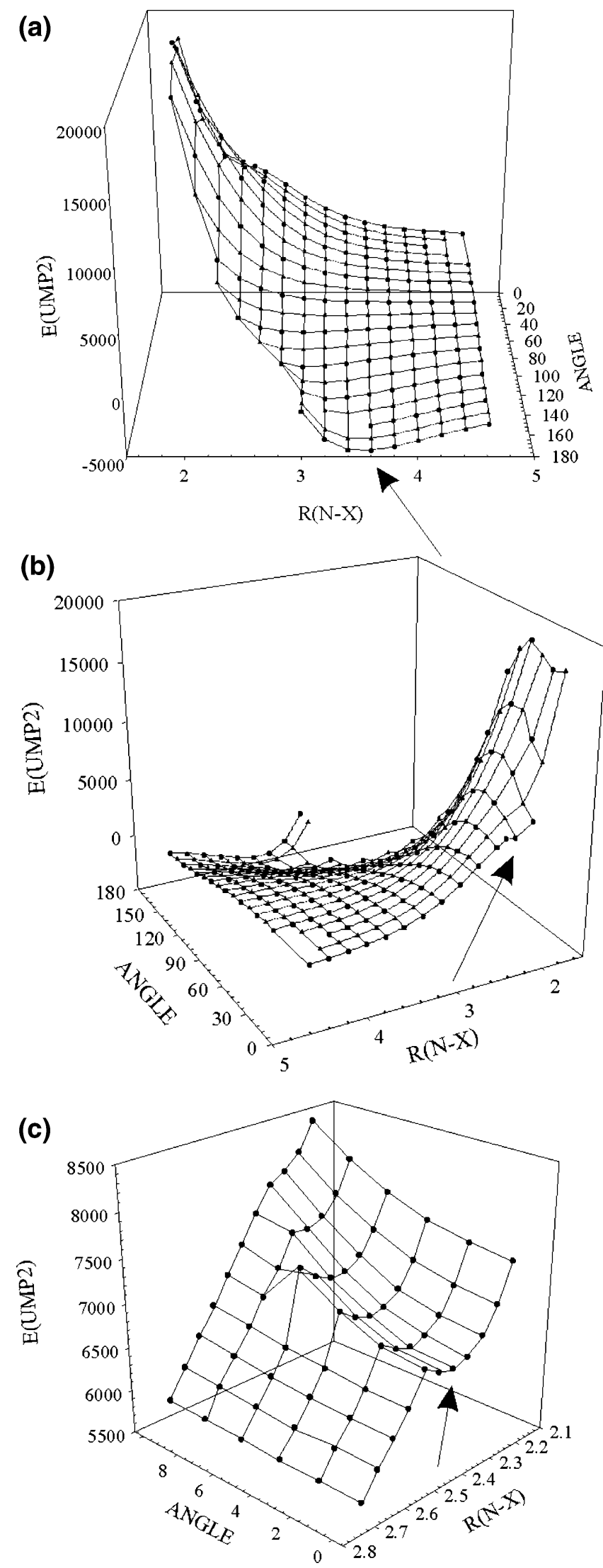

Figure 3. MP2 energies $\left(\mathrm{cm}^{-1}\right)$ for the $\mathrm{Me}_{3} \mathrm{~N}-\mathrm{Na}-\mathrm{H}$ system as a function of the distance $\mathrm{R}(\mathrm{N}-\mathrm{X})(\AA)$ from $\mathrm{N}$ to the center $(\mathrm{X})$ of the $\mathrm{Na}-\mathrm{H}$ and the angle (deg) between $\mathrm{Me}_{3} \mathrm{~N}^{\prime} C_{3 v}$ axis and the $\mathrm{Na}-\mathrm{H}$ internuclear axis. View (a) shows the $\mathrm{Me}_{3} \mathrm{~N}-\mathrm{Na}^{+} \cdot \cdots \mathrm{H}^{-}$minimum (arrow); view (b) shows the $\mathrm{Me}_{3} \mathrm{~N}-\mathrm{H}^{+} \cdot \cdots \mathrm{Na}^{-}$local minimum (arrow); and view (c) is a more narrowly focused version of view (b). 


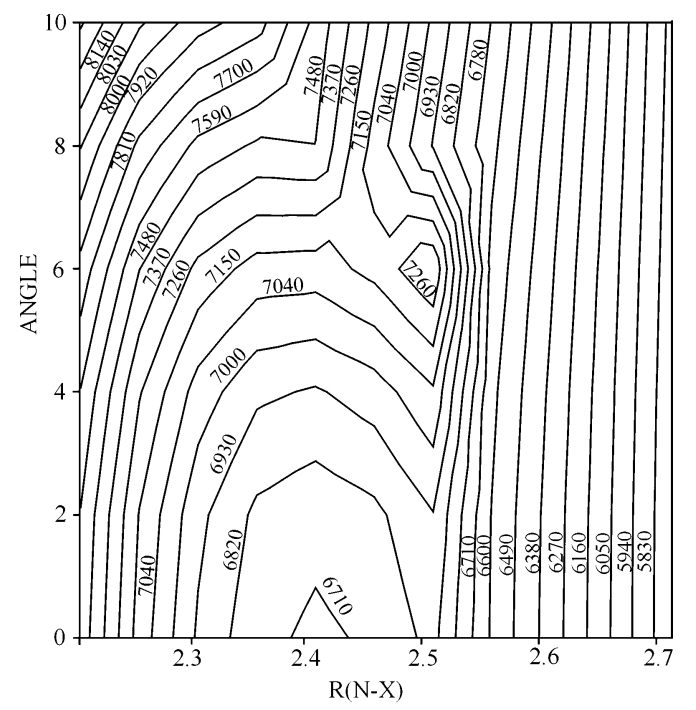

Figure 4. Contour plot of MP2 energies $\left(\mathrm{cm}^{-1}\right)$ in the region of the $\mathrm{Me}_{3} \mathrm{~N}-\mathrm{H}^{+} \cdot \cdots \mathrm{Na}^{-}$local minimum also showing the transition state.

we intend to consider species with more than one amine site to which the $\mathrm{H}^{+}$can bind to further enhance chances of forming a stable $-\mathrm{H}^{+} \cdot . \cdot \mathrm{M}^{-}$ion pair, but in the present effort we restrict our attention to molecules containing one amine site.

\section{Methods}

We first optimized the geometries of the species studied in this paper $\left(\mathrm{Et}_{3} \mathrm{NH}^{+} \cdot \cdot \mathrm{K}^{-}, \mathrm{Et}_{3} \mathrm{NK}^{+} \cdot \cdot \mathrm{H}^{-}\right)$at the second-order Møller-Plesset perturbation theory level. ${ }^{7} \mathrm{We}$ also calculated all vibrational frequencies to make sure the structures thus found were indeed minima on the energy surface. Based upon these optimized geometries, we performed single-point energy calculations at higher orders of Møller-Plesset perturbation theory ${ }^{7}$ (MP $n, n=3,4)$ and at the coupled cluster level with single and double excitations supplemented with a perturbative treatment of triple excitations $(\operatorname{CCSD}(\mathrm{T})){ }^{8}$

Second-order Møller-Plesset perturbation theory was used to perform the scans of the ground-state potential energy surface for the ion-pair interactions, $\mathrm{K}^{-}+\mathrm{Et}_{3} \mathrm{NH}^{+}$and $\mathrm{H}^{-}+\mathrm{Et}_{3} \mathrm{NK}^{+}$. To achieve a broader view of these reactions, we also studied the potential energy surface of the $\mathrm{Et}_{3} \mathrm{NH}^{+} \cdot . \mathrm{K}^{-}$complex for various NHK angles and distances at the restricted HartreeFock (RHF) and MP2 levels of theory. In all of these calculations, we used $6-311++\mathrm{G}^{* *}$ basis sets. ${ }^{9}$ The use of an extra diffuse function is not required in this study because none of the anions involved has a diffuse enough charge density. In

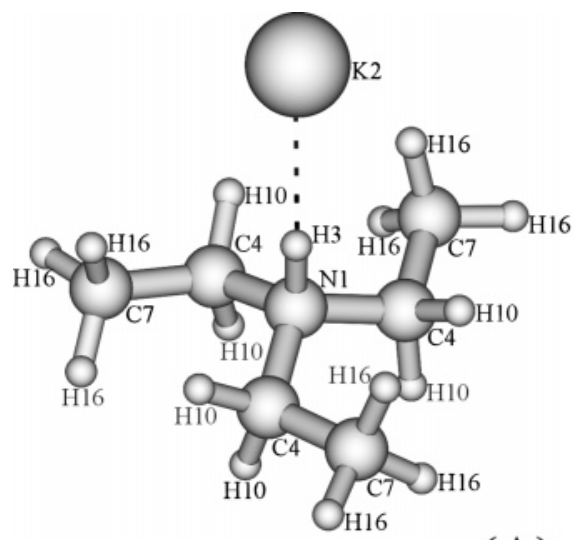

(A) other words, both $\mathrm{H}^{-}$and $\mathrm{K}^{-}$bind their excess electron strongly enough to not require special diffuse basis sets.

All of the ab initio calculations presented in this study were performed using the Gaussian $98^{10}$ and Gaussian $03^{11}$ suites of codes. They were carried out on the Utah Center for High Performance Computing machines, our group's AMD Athlon 2.0 GHz computers, and the Academic Computer Center in Gdansk (TASK) machines.

\section{Results}

A. The Ground-State Potential Energy Surface of $\mathbf{E t}_{3} \mathbf{N}$ + KH. The results of our optimizations on the geometrical structures of both systems $\left(\mathrm{Et}_{3} \mathrm{~N}-\mathrm{H}^{+} \cdot . \cdot \mathrm{K}^{-}\right.$and $\mathrm{Et}_{3} \mathrm{~N}-\mathrm{K}^{+} \cdot$. $\mathrm{H}^{-}$) studied in this paper are characterized in Table 1. As is seen in Figure 5, the $\mathrm{Et}_{3} \mathrm{~N}-\mathrm{K}^{+} \cdot \cdot \mathrm{H}^{-}$complex has no symmetry and the hydrogen atom bonded to the nitrogen is not on the nominal $C_{3}$ axis of the amine as it was found to be in $\mathrm{Me}_{3} \mathrm{~N}-$ $\mathrm{H}^{+} \cdot \cdot \mathrm{Na}^{-}$. The MP2 scans of the ground-state potential energy surface for the ion-pair interactions, $\mathrm{K}^{-}+\mathrm{Et}_{3} \mathrm{NH}^{+}$and $\mathrm{H}^{-}+$ $\mathrm{Et}_{3} \mathrm{NK}^{+}$, are presented in Figures 6-8.

In Figure 6, we describe the connection of $\mathrm{KH}$ and $\mathrm{Et}_{3} \mathrm{~N}$ along two paths obtained by varying the distance between the $\mathrm{N}$ and $\mathrm{H}$ atoms and between the $\mathrm{N}$ and $\mathrm{K}$ atoms in $\mathrm{Et}_{3} \mathrm{~N}-\mathrm{H}^{+} \cdot \cdots \mathrm{K}^{-}$ and $\mathrm{Et}_{3} \mathrm{~N}-\mathrm{K}^{+} \cdot \cdot \mathrm{H}^{-}$, respectively, while all other geometry parameters were optimized. The sum of the $\mathrm{Et}_{3} \mathrm{~N}$ and KH MP2 equilibrium energies is -891.4233621 hartrees and is defined as the reference point (i.e., zero of energy) for all energies shown in Figures 6-8. In Figure 6, the lower-energy path connects to the $\mathrm{Et}_{3} \mathrm{~N}-\mathrm{K}^{+} \cdot \cdot \cdot \mathrm{H}^{-}$ion-pair complex as the $\mathrm{K}-\mathrm{N}$ distance is scanned. The higher-energy path connects to the $\mathrm{Et}_{3} \mathrm{~N}-\mathrm{H}^{+} \ldots$ $\mathrm{K}^{-}$complex as the $\mathrm{H}-\mathrm{N}$ distance is scanned.

Based on the results of our earlier work, it is not surprising that the $\mathrm{Et}_{3} \mathrm{~N}-\mathrm{H}^{+} \cdot \cdots \mathrm{K}^{-}$complex appears as a locally geometrically stable structure with a barrier to dissociation (of ca. $2853 \mathrm{~cm}^{-1}$ or $8 \mathrm{kcal} \mathrm{mol}^{-1}$ computed at the $\operatorname{CCSD}(\mathrm{T})$ level ${ }^{12}$ ). The stability of this system is also supported by the fact that all calculated harmonic vibrational frequencies are real. As Figure 6 illustrates, $\mathrm{Et}_{3} \mathrm{~N}-\mathrm{H}^{+} . . \cdot \mathrm{K}^{-}$lies ca. $6600 \mathrm{~cm}^{-1}$ above the $\mathrm{Et}_{3} \mathrm{~N}+\mathrm{KH}$ asymptote.

To have a better view of this minimum and for comparison with results included in our previous work, we also computed the MP2 energy of this system by varying the distance $R(\mathrm{~N}-$ $\mathrm{X}$ ) between the $\mathrm{N}$ atom and the midpoint (denoted $\mathrm{X}$ ) of the $\mathrm{K}-\mathrm{H}$ bond and the HXN angles, all other degrees of freedom being optimized to minimize the energy. Figure 7a shows the $\mathrm{Et}_{3} \mathrm{~N}-\mathrm{H}^{+} \cdot \cdots \mathrm{K}^{-}$region (angle $=0^{\circ}$ ) and the region (angle $=$ $118^{\circ}$ ) of the $\mathrm{Et}_{3} \mathrm{~N}-\mathrm{K}^{+} \cdot \cdot \mathrm{H}^{-}$complex (both labeled by arrows).

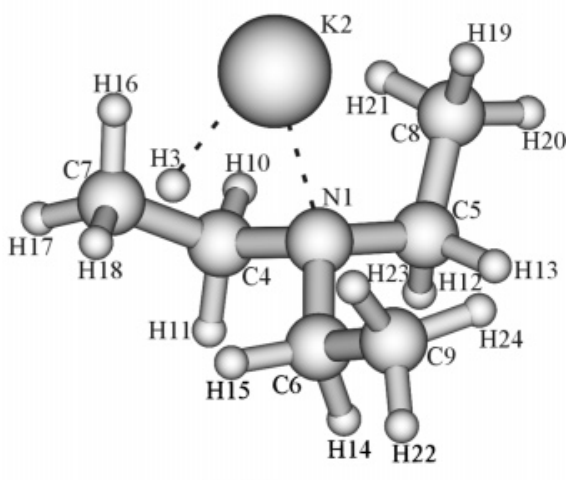

(B)

Figure 5. The equilibrium geometries of the (A) $\mathrm{Et}_{3} \mathrm{~N}-\mathrm{H}^{+} \cdots \mathrm{K}^{-}$and (B) $\mathrm{Et}_{3} \mathrm{~N}-\mathrm{K}^{+} \cdot \cdots \mathrm{H}^{-}$complexes. 


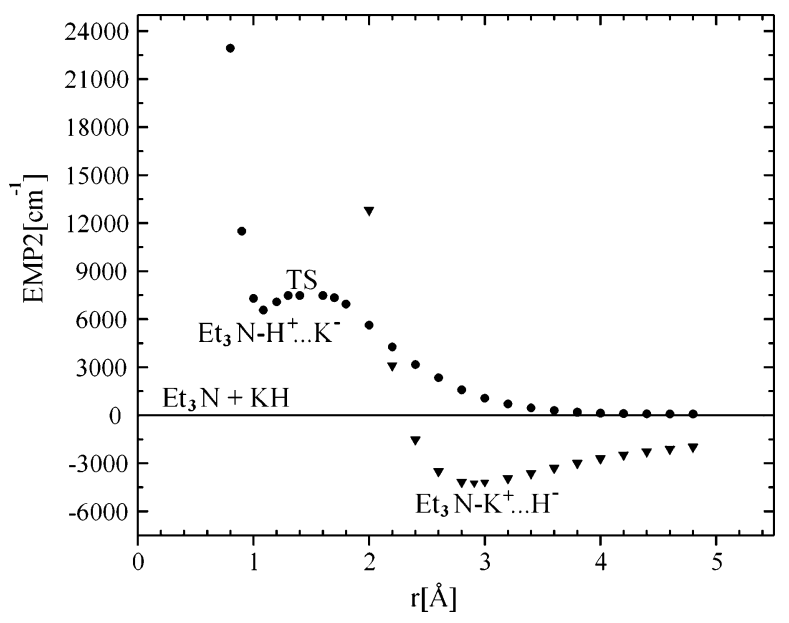

Figure 6. MP2 energies $\left(\mathrm{cm}^{-1}\right)$ connecting $\mathrm{Et}_{3} \mathrm{~N}+\mathrm{KH}$ to $\mathrm{Et}_{3} \mathrm{~N}-\mathrm{K}^{+}$. $\cdot \cdot \mathrm{H}^{-}$(lower curve) and to $\mathrm{Et}_{3} \mathrm{~N}-\mathrm{H}^{+} \cdot \cdot \mathrm{K}^{-}$(upper curve). Here, $r$ is the distance from $\mathrm{N}$ to $\mathrm{H}$ in the upper curve and from the $\mathrm{N}$ to the $\mathrm{K}$ atom in the lower curve.

In Figure $7 \mathrm{~b}$, the presence of a local minimum near $R(\mathrm{~N}-\mathrm{X})$ $=2.7 \AA$ and angle $=0^{\circ}$ is especially clear.

In Figure 8, we display the kind of data shown in Figure $7 \mathrm{~b}$ with the radial and angular coordinates focused near the $\mathrm{Et}_{3} \mathrm{~N}-$ $\mathrm{H}^{+} \cdot . \cdot \mathrm{K}^{-}$minimum near $\theta=0^{\circ}$ and $R(\mathrm{~N}-\mathrm{X})=2.7 \AA$. The transition state is observed near $R(\mathrm{~N}-\mathrm{X})=2.8 \AA$ and $\theta=5^{\circ}$ degrees.

B. Comparison of the $\mathrm{Me}_{3} \mathrm{~N}-\mathrm{H}^{+} \cdot \mathrm{Na}^{-}$and $\mathrm{Et}_{3} \mathrm{~N}-$ $\mathbf{H}^{+} \cdot . \mathbf{K}^{-}$Complexes. Let us now compare the results for the two candidate systems studied so far in our work. Both contain a combination of a protonated amine with an alkali metal anion. The main differences are in the proton affinities of the two amines and the strengths of the hydrogen-metal bonds. We expected that the $\mathrm{Et}_{3} \mathrm{~N}-\mathrm{H}^{+} \cdot \cdots \mathrm{K}^{-}$ion pair, with the stronger $\mathrm{R}_{3} \mathrm{~N}-\mathrm{H}^{+}$bonding and weaker $\mathrm{M}-\mathrm{H}$ bonding, would be more stable and have a larger barrier to dissociation. Indeed, this turned out to be the case. As our data suggest, both systems are locally geometrically stable. $\mathrm{Me}_{3} \mathrm{~N}-\mathrm{H}^{+} \cdot \cdots \mathrm{K}^{-}$has to overcome an ca. $2 \mathrm{kcal} \mathrm{mol}^{-1}$ barrier to fall apart to form $\mathrm{Me}_{3} \mathrm{~N}$ and $\mathrm{HNa}$, while the barrier for $\mathrm{Et}_{3} \mathrm{~N}-\mathrm{H}^{+} \cdot \cdots \mathrm{K}^{-}$is about 4 times higher $\left(8 \mathrm{kcal} \mathrm{mol}^{-1}\right)$. The depths of the $\mathrm{Me}_{3} \mathrm{~N}-\mathrm{H}^{+} \cdot . \cdot \mathrm{K}^{-}$and
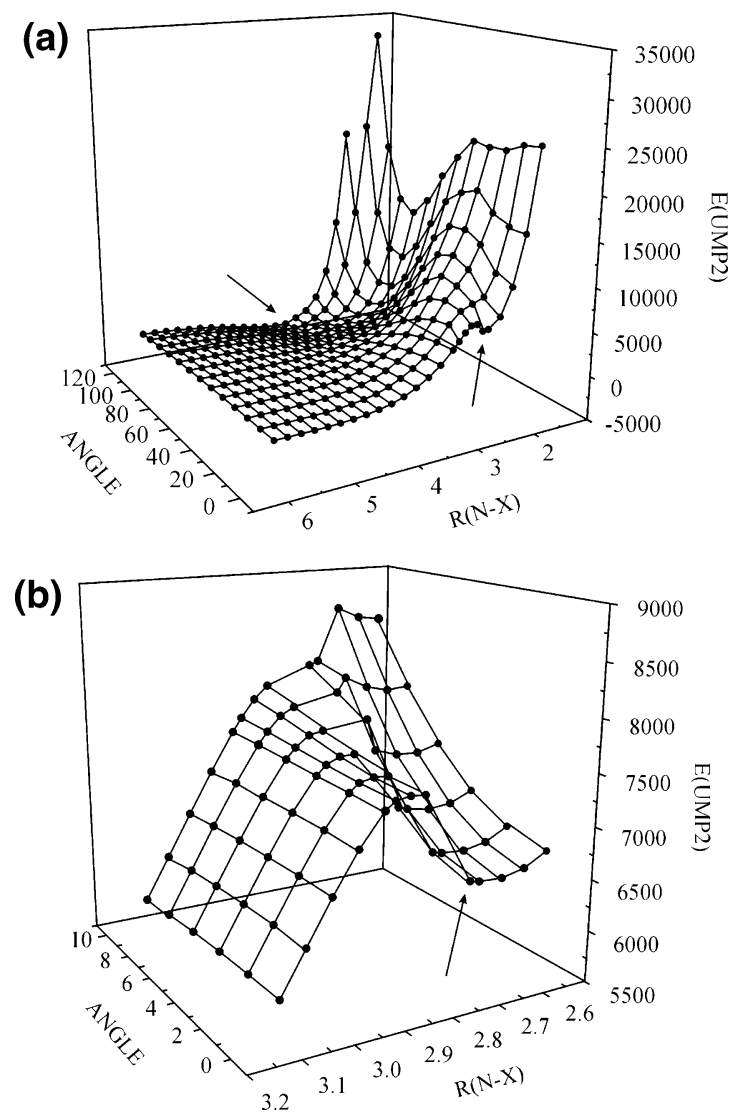

Figure 7. MP2 energies $\left(\mathrm{cm}^{-1}\right)$ for the $\mathrm{Et}_{3} \mathrm{~N}-\mathrm{K}-\mathrm{H}$ system as a function of the distance $(\mathrm{N}-\mathrm{X})(\AA)$ from $\mathrm{N}$ to the center of the $\mathrm{K}-\mathrm{H}$ and $\mathrm{HXN}$ angle (deg). View (a) shows the $\mathrm{Et}_{3} \mathrm{~N}-\mathrm{H}^{+} \cdots \mathrm{K}^{-}$minimum, the $\mathrm{Et}_{3} \mathrm{~N}-\mathrm{K}^{+} \cdots \mathrm{H}^{-}$minimum (arrows), and the transition state; view (b) shows the $\mathrm{Et}_{3} \mathrm{~N}-\mathrm{H}^{+} \cdots \mathrm{K}^{-}$minimum in more detail.

$\mathrm{Et}_{3} \mathrm{~N}-\mathrm{H}^{+} \cdot . \mathrm{K}^{-}$minima are especially clear in Figures $3 \mathrm{c}$ and Figure $7 b$, respectively.

In our previous work on $\mathrm{Me}_{3} \mathrm{~N}-\mathrm{H}^{+} \cdot \cdot \mathrm{Na}^{-}$, we also explored how the height of the barrier depends on the solvation environments. The data we obtained in that ab initio theoretical investigation indicated that proper solvent conditions may indeed be essential for forming a metastable (i.e., locally geometrically stable with a significant barrier to dissociation) "inverse" charge

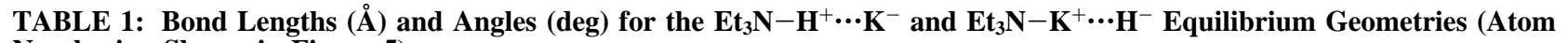
Numbering Shown in Figure 5)

$$
\begin{aligned}
& r(\mathrm{~N} 1 \mathrm{H} 3)=1.085 \\
& r(\mathrm{~K} 2 \mathrm{H} 3)=3.177 \\
& r(\mathrm{C} 4 \mathrm{~N} 1)=1.499 \\
& r(\mathrm{C} 4 \mathrm{C} 7)=1.523 \\
& r(\mathrm{H} 10 \mathrm{C} 4)=1.094 \\
& r(\mathrm{H} 16 \mathrm{C} 7)=1.093
\end{aligned}
$$

$r(\mathrm{~N} 1 \mathrm{~K} 2)=2.908$

$r(\mathrm{C} 6 \mathrm{H} 14)=1.100$

$r(\mathrm{~K} 2 \mathrm{H} 3)=2.305$

$r(\mathrm{C} 4 \mathrm{H} 10)=1.094$

$r(\mathrm{~N} 1 \mathrm{C} 6)=1.481$

$r(\mathrm{~N} 1 \mathrm{C} 4)=1.478$

$r(\mathrm{~N} 1 \mathrm{C} 5)=1.472$

$r(\mathrm{C} 4 \mathrm{C} 7)=1.526$

$r(\mathrm{C} 6 \mathrm{C} 9)=1.525$

$r(\mathrm{C} 5 \mathrm{C} 8)=1.525$

$r(\mathrm{C} 8 \mathrm{H} 19)=1.095$

$r(\mathrm{C} 8 \mathrm{H} 20)=1.094$

$r(\mathrm{C} 8 \mathrm{H} 21)=1.094$

$r(\mathrm{C} 6 \mathrm{H} 15)=1.094$

\section{$\mathrm{Et}_{3} \mathrm{~N}-\mathrm{H}^{+} \cdots \mathrm{K}^{-}$}

$$
\begin{aligned}
& \theta(\mathrm{N} 1 \mathrm{H} 3 \mathrm{~K} 2)=180.0 \\
& \theta(\mathrm{C} 4 \mathrm{~N} 1 \mathrm{H} 3)=106.277 \\
& \theta(\mathrm{C} 7 \mathrm{C} 5 \mathrm{~N} 1)=113.537 \\
& \theta(\mathrm{H} 10 \mathrm{C} 5 \mathrm{~N} 1)=106.299 \\
& \theta(\mathrm{H} 16 \mathrm{C} 7 \mathrm{C} 4)=110.383
\end{aligned}
$$

$\theta(\mathrm{H} 13 \mathrm{C} 5 \mathrm{~N} 1)=108.339$
$\theta(\mathrm{H} 12 \mathrm{C} 5 \mathrm{~N} 1)=110.111$
$\theta(\mathrm{H} 22 \mathrm{C} 9 \mathrm{C})=109.494$
$\theta(\mathrm{H} 23 \mathrm{C} 9 \mathrm{C} 6)=110.016$
$\theta(\mathrm{H} 24 \mathrm{C} 9 \mathrm{C} 6)=112.401$
$\theta(\mathrm{H} 16 \mathrm{C} 7 \mathrm{C} 4)=110.693$
$\theta(\mathrm{H} 17 \mathrm{C} 7 \mathrm{C} 4)=110.177$
$\theta(\mathrm{H} 18 \mathrm{C} 7 \mathrm{C} 4)=112.303$
$\theta(\mathrm{H} 19 \mathrm{C} 8 \mathrm{C} 5)=110.412$
$\theta(\mathrm{H} 20 \mathrm{C} 8 \mathrm{C} 5)=110.469$
$\theta(\mathrm{H} 21 \mathrm{C} 8 \mathrm{C} 5)=111.885$

$\begin{array}{ll}r(\mathrm{C} 4 \mathrm{H} 11)=1.104 & \theta(\mathrm{C} 7 \mathrm{C} 4 \mathrm{~N} 1)=112.881 \\ r(\mathrm{C} 5 \mathrm{H} 12)=1.105 & \theta(\mathrm{C} 8 \mathrm{C} 5 \mathrm{~N} 1)=112.352 \\ r(\mathrm{C} 5 \mathrm{H} 13)=1.093 & \theta(\mathrm{C} 9 \mathrm{C} 6 \mathrm{~N} 1)=113.569 \\ r(\mathrm{C} 7 \mathrm{H} 16)=1.096 & \theta(\mathrm{H} 11 \mathrm{C} 4 \mathrm{~N} 1)=109.296 \\ r(\mathrm{C} 7 \mathrm{H} 17)=1.094 & \theta(10 \mathrm{C} 4 \mathrm{~N} 1)=108.470 \\ r(\mathrm{C} 7 \mathrm{H} 18)=1.093 & \theta(\mathrm{H} 15 \mathrm{C} 6 \mathrm{~N} 1)=107.799 \\ r(\mathrm{C} 9 \mathrm{H} 22)=1.094 & \theta(\mathrm{H} 14 \mathrm{C} 6 \mathrm{~N} 1)=108.982\end{array}$

$r(\mathrm{C} 9 \mathrm{H} 23)=1.094$

$r(\mathrm{C} 9 \mathrm{H} 24)=1.094$ 


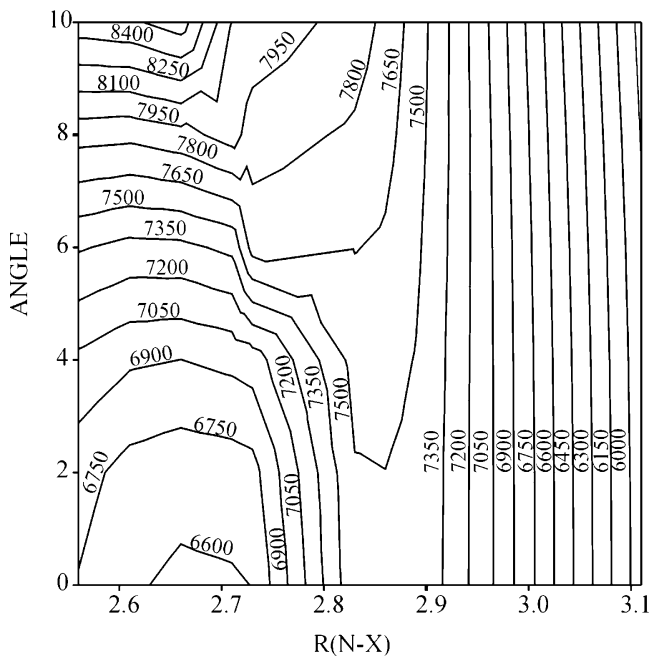

Figure 8. Contour plot of MP2 energies $\left(\mathrm{cm}^{-1}\right)$ in the region of the $\mathrm{Et}_{3} \mathrm{~N}-\mathrm{H}^{+} \cdot \cdots \mathrm{K}^{-}$local minimum and the transition state.

state ion pair. The same situation is expected for $\mathrm{Et}_{3} \mathrm{~N}-\mathrm{H}-\mathrm{K}$ that we examined in the present study, so we did not repeat the model solvation study carried out earlier.

\section{Summary}

When the unusual charge state of $\mathrm{H}^{+}$and $\mathrm{Na}^{-}$was reported in a novel experimental study of the Dye group, we decided to take a closer look at this issue. We attempted to find a nonsequestered system with a barrier to charge exchange that might lead to a long-lived metastable state for the chargereversed ion pair. We found that by using an amine with a large proton affinity (PA) and an alkali metal with a weak $\mathrm{M}-\mathrm{H}$ bond, a significant barrier to deprotonation can be achieved. The results of our calculations on the high-energy $\mathrm{Et}_{3} \mathrm{~N}-\mathrm{H}^{+} \cdots \mathrm{K}^{-}$ion pair suggest that this system is indeed metastable with respect to proton abstraction with an $8 \mathrm{kcal} \mathrm{mol}^{-1}$ barrier to dissociation. This is a 4-fold increase in the barrier height as compared to the results we obtained for $\mathrm{Me}_{3} \mathrm{~N}-\mathrm{H}^{+} \cdot \ldots \mathrm{Na}^{-}$in our earlier work where the barrier to dissociation was calculated to be ca. $2 \mathrm{kcal}$ $\mathrm{mol}^{-1}$. We believe the results presented here are interesting enough to encourage further laboratory studies of the possibilities put forth here. In particular, the data from this paper suggest that unprotected protonated amines complexed with alkali metal anions might be synthesized if the appropriate precursors and reaction conditions (especially low-dielectric solvents) can be identified and exploited.

What we plan to do next along these lines is to consider whether protonated sites (e.g., $\mathrm{R}_{3} \mathrm{~N}-\mathrm{H}^{+}$or $\mathrm{R}_{2} \mathrm{O}-\mathrm{H}^{+}$) can be used to form electrides. Such species are related to the inverse charge-state $-\mathrm{H}^{+} \cdot \cdots \mathrm{M}^{-}$systems treated in the present paper with the alkali anion $\mathrm{M}^{-}$replaced by an electron $\mathrm{e}^{-}$. As the Dye group has pointed out, it has not proven possible to form electrides using even sequestered protonated amines such as shown in Figure 1. This is because the electron can enter the cage and break the $\mathrm{N}-\mathrm{H}^{+}$bond (n.b., the $\mathrm{N}-\mathrm{H}^{+}$bond strength may be $200 \mathrm{kcal} \mathrm{mol}^{-1}$, but this is more than offset by the 13.6 $\mathrm{eV}$ gained when the electron neutralizes $\mathrm{H}^{+}$). We are going to explore whether a cage compound similar to that shown in Figure 1, but larger to accommodate the ammonium cation, with $\mathrm{NH}_{4}{ }^{+}$sequestered inside might remain stable to electron neutralization and thus be a good candidate for forming an electride system. We base this suggestion on noting that to attach an electron to $\mathrm{NH}_{4}{ }^{+}$to form $\mathrm{NH}_{4}$, which would then easily (i.e., over a small barrier) fragment to $\mathrm{NH}_{3}+\mathrm{H}$, the electron must be able to enter a Rydberg-like orbital of $\mathrm{NH}_{4}$. However, with $\mathrm{NH}_{4}{ }^{+}$solvated by the $\mathrm{N}$ atoms within the cage, such a Rydberg orbital would not be energetically accessible (i.e., it would be "squeezed" by the surrounding $\mathrm{N}$ atoms and the hydrocarbon backbone of the cage), and thus electron attachment to it might not occur. ${ }^{13}$ Instead, the electron would be expected to remain exterior to the caged ammonium cation. Of course, these are mere speculations whose detailed examination we need to report on in a future manuscript.

Acknowledgment. This work was supported by NSF Grants 9982420 and 0240387 to J.S. and the Polish State Committee for Scientific Research (KBN) Grant No. DS/8371-4-0137-2 to P.S. The computer time provided by the Center for High Performance Computing at the University of Utah is also gratefully acknowledged.

\section{References and Notes}

(1) Redko, M. Y.; Vlassa, M.; Jackson, J. E.; Misiolek, A. W.; Huang, R. H.; Dye, J. L. J. Am. Chem. Soc. 2002, 124, 5928-5929.

(2) Kuchenmeister, M. E.; Dye, J. L. J. Am. Chem. Soc. 1989, 111, 935-938.

(3) Sawicka, A.; Skurski, P.; Simons, J. J. Am. Chem. Soc. 2003, 125, 3954-3958.

(4) Miertus, S.; Scrocco, E.; Tomasi, J. Chem. Phys. 1981, 55, 117. Miertus, S.; Tomasi, J. Chem. Phys. 1982, 65, 239. Cossi, M.; Barone, V.; Cammi, R.; Tomasi, J. Chem. Phys. Lett. 1996, 255, 327.

(5) We can estimate the dissociation rate of such a complex by multiplying the $\mathrm{N}-\mathrm{H}^{+}$vibrational frequency (ca. $10^{14} \mathrm{~s}^{-1}$ ) by the probability $P=\exp (-E / k T)$ of accessing the $E=2 \mathrm{kcal} \mathrm{mol}^{-1}$ barrier. We obtain 3 $\times 10^{12} \mathrm{~s}^{-1}$ at $T=298 \mathrm{~K}$ and $2 \times 10^{8} \mathrm{~s}^{-1}$ at $77 \mathrm{~K}$, both of which are far too fast to easily be realized in the laboratory.

(6) $\mathrm{KH}$ has a bond energy of ca. $1.8 \mathrm{eV}$; others are $\mathrm{LiH}(2.5 \mathrm{eV}), \mathrm{NaH}$ $(2.2 \mathrm{eV})$, and $\mathrm{RbH}(1.9 \mathrm{eV})$ as given in: Herzberg, G. Spectra of Diatomic Molecules; van Nostrand: New York, 1950.

(7) Roothaan, C. C. J. Rev. Mod. Phys. 1960, 32, 179. Binkley, J. S. Pople, J. A.; Dobosh, P. A. Mol. Phys. 1974, 28, 1423. Møller, C.; Plesset, M. S. Phys. Rev. 1934, 46, 618. Binkley, J. S.; Pople, J. A. Int. J. Quantum Chem. 1975, 9, 229. Head-Gordon, M.; Pople, J. A.; Frisch, M. J. Chem. Phys. Lett. 1988, 153, 503. Frisch, M. J.; Head-Gordon, M.; Pople, J. A. Chem. Phys. Lett. 1990, 166, 275. Frisch, M. J.; Head-Gordon, M.; Pople, J. A. Chem. Phys. Lett. 1990, 166, 281. Saebo, S.; Almlöf, J. Chem. Phys. Lett. 1989, 154, 83.

(8) Purvis, G. D.; Bartlett, R. J. J. Chem. Phys. 1982, 76, 1910. Ragavachari, K.; Trucks, G. W.; Pople, J. A.; Head-Gordon, M. Chem. Phys. Lett. 1989, 157, 479.

(9) McLean, A. D.; Chandler, G. S. J. Chem. Phys. 1980, 72, 5639. Krishan, R.; Binkley, J. S.; Seeger, R.; Pople, J. A. J. Chem. Phys. 1980, 72, 650. Blaudeau, J.-P.; McGrath, M. P.; Curtiss, L. A.; Radom, L. J. Chem. Phys. 1997, 107, 5016.

(10) Frisch, M. J.; Trucks, G. W.; Schlegel, H. B.; Scuseria, G. E.; Robb, M. A.; Cheeseman, J. R.; Zakrzewski, V. G.; Montgomery, J. A., Jr.; Stratmann, R. E.; Burant, J. C.; Dapprich, S.; Millam, J. M.; Daniels, A. D.; Kudin, K. N.; Strain, M. C.; Farkas, O.; Tomasi, J.; Barone, V.; Cossi, M.; Cammi, R.; Mennucci, B.; Pomelli, C.; Adamo, C.; Clifford, S. Ochterski, J.; Petersson, G. A.; Ayala, P. Y.; Cui, Q.; Morokuma, K.; Malick, D. K.; Rabuck, A. D.; Raghavachari, K.; Foresman, J. B.; Cioslowski, J.; Ortiz, J. V.; Baboul, A. G.; Stefanov, B. B.; Liu, G.; Liashenko, A.; Piskorz, P.; Komaromi, I.; Gomperts, R.; Martin, R. L.; Fox, D. J.; Keith, T.; AlLaham, M. A.; Peng, C. Y.; Nanayakkara, A.; Gonzalez, C.; Challacombe, M.; Gill, P. M. W.; Johnson, B.; Chen, W.; Wong, M. W.; Andres, J. L.; Gonzalez, C.; Head-Gordon, M.; Replogle, E. S.; Pople, J. A. Gaussian 98, revision A.7; Gaussian, Inc.: Pittsburgh, PA, 1998.

(11) Frisch, M. J.; Trucks, G. W.; Schlegel, H. B.; Scuseria, G. E.; Robb, M. A.; Cheeseman, J. R.; Montgomery, J. A., Jr.; Vreven, T.; Kudin, K. N.; Burant, J. C.; Millam, J. M.; Iyengar, S. S.; Tomasi, J.; Barone, V.; Mennucci, B.; Cossi, M.; Scalmani, G.; Rega, N.; Petersson, G. A.; Nakatsuji, H.; Hada, M.; Ehara, M.; Toyota, K.; Fukuda, R.; Hasegawa, J.; Ishida, M.; Nakajima, T.; Honda, Y.; Kitao, O.; Nakai, H.; Klene, M.; Li, X.; Knox, J. E.; Hratchian, H. P.; Cross, J. B.; Adamo, C.; Jaramillo, J.; Gomperts, R.; Stratmann, R. E.; Yazyev, O.; Austin, A. J.; Cammi, R.; Pomelli, C.; Ochterski, J. W.; Ayala, P. Y.; Morokuma, K.; Voth, G. A.; Salvador, P.; Dannenberg, J. J.; Zakrzewski, V. G.; Dapprich, S.; Daniels, 
A. D.; Strain, M. C.; Farkas, O.; Malick, D. K.; Rabuck, A. D.; Raghavachari, K.; Foresman, J. B.; Ortiz, J. V.; Cui, Q.; Baboul, A. G.; Clifford, S.; Cioslowski, J.; Stefanov, B. B.; Liu, G.; Liashenko, A.; Piskorz, P.; Komaromi, I.; Martin, R. L.; Fox, D. J.; Keith, T.; Al-Laham, M. A.; Peng, C. Y.; Nanayakkara, A.; Challacombe, M.; Gill, P. M. W.; Johnson, B.; Chen, W.; Wong, M. W.; Gonzalez, C.; Pople, J. A. Gaussian 03, revision A.1; Gaussian, Inc.: Pittsburgh, PA, 2003

(12) As explained in ref 5, the rate of dissociation of this complex can be estimated to be $1 \times 10^{8} \mathrm{~s}^{-1}$ at $298 \mathrm{~K}$ and $2 \times 10^{-9} \mathrm{~s}^{-1}$ at $77 \mathrm{~K}$; the latter suggests that the species might be long-lived if kept at low temperatures and in low-dielectric solvents.

(13) As shown in: Ortiz, J. V. J. Chem. Phys. 2002, 117, 5748. An $\mathrm{NH}_{4}{ }^{+}$cation with one $\mathrm{NH}_{3}$ molecule attached can still bind one or two electrons in a Rydberg-like orbital. However, we think that when $\mathrm{NH}_{4}{ }^{+}$is surrounded by four nitrogen lone pair orbitals as in the compounds we suggest studying, this will no longer be feasible; instead, an electron is expected to bind exterior to the cage in which the $\mathrm{NH}_{4}{ }^{+}$is sequestered. 